ORIGINAL ARTICLE

\title{
Diversity and abundance of green lacewings (Neuroptera: Chrysopidae) in a Conilon coffee plantation in Acre, Brazil
}

\author{
Caleb Califre MARTINS ${ }^{*}$ (), Rodrigo Souza SANTOS², Weidson Plauter SUTIL ${ }^{3}$, \\ José Fernando Araújo de OLIVEIRA ${ }^{4}$ \\ ${ }^{1}$ Universidade de São Paulo, Faculdade de Filosofia Ciências e Letras de Ribeirão Preto, Av. Bandeirantes 3900, 14040-901, Ribeirão Preto, SP, Brasil \\ 2 Empresa Brasileira de Pesquisa Agropecuária, Rodovia BR 364, Km 14, CP 321, 69900-970, Rio Branco, AC, Brasil \\ ${ }^{3}$ Universidade Federal do Acre, Programa de Pós-Graduação em Produção Vegetal, Rodovia BR 364, Km 04 - Distrito Industrial, 69920-900, Rio Branco, AC, Brasil \\ ${ }^{4}$ União Educacional do Norte, Alameda Hungria 200, Jardim Europa, 69915-901, Rio Branco, AC, Brasil \\ * Corresponding author: calebcalifre@gmail.com; (10) https://orcid.org/0000-0001-5630-9865
}

\section{ABSTRACT}

Coffea canephora (Conilon coffee) has great economic importance for the state of Acre, in northern Brazil. The use of insecticides in this crop has increased considerably in recent years. In order to find species of green lacewing (Chrysopidae, Neuroptera) with potential for use in biological pest control in coffee plantations, we sampled green lacewings during one year in an experimental plantation of Conilon coffee in Acre, in order to assess the diversity, abundance and seasonal occurrence of Chrysopidae species. Samplings were carried out weekly using an entomological net. Overall, 1079 specimens of seven green lacewing species were collected: Ceraeochrysa cincta, Ceraeochrysa claveri, Ceraeochrysa cubana, Ceraeochrysa everes, Chrysoperla externa, Leucochrysa (Nodita) cruentata and Leucochrysa (Nodita) marquezi. Ceraeochrysa cubana was the dominant and constant species, comprising $97 \%$ of the sampled specimens and occurring in $82 \%$ of the weekly samples. The abundance and constant presence of C. cubana, which preys upon several agricultural pests and has shown resistance to various insecticides, make this species a potential candidate for future programs of biological control in Conilon coffee plantations in the southwestern Brazilian Amazon region.

KEYWORDS: Neuropterida, Chrysopoidea, species diversity, Rubiaceae

\section{Diversidade e abundância de crisopídeos (Neuroptera: Chrysopidae) em cultivo de café Conilon no Acre, Brasil}

\section{RESUMO}

Coffea canephora (café Conilon) tem grande importância econômica para o estado do Acre, porém o uso de inseticidas nessa cultura tem aumentado consideravelmente nos últimos anos. A fim de prospectar espécies de Chrysopidae (Neuroptera) com potencial para uso em programas de controle biológico de pragas dessa cultura, nós amostramos crisopídeos em um plantio experimental de café Conilon no Acre durante um ano, para avaliar a diversidade, abundância e ocorrência sazonal de espécies deste grupo de insetos. As amostragens foram semanais por meio do uso de rede entomológica. Foram coletados 1079 espécimes de sete espécies de crisopídeos: Ceraeochrysa cincta, Ceraeochrysa claveri, Ceraeochrysa cubana, Ceraeochrysa everes, Chrysoperla externa, Leucochrysa (Nodita) cruentata and Leucochrysa (Nodita) marquezi. Ceraeochrysa cubana foi a espécie mais dominante e constante, constituindo $97 \%$ dos exemplares coletados e ocorrendo em $82 \%$ das amostras. Esses resultados, somados ao fato de que C. cubana é predadora de diversas pragas agrícolas e possui resistência a vários inseticidas, indicam que essa espécie é candidata potencial para o uso em futuros programas de controle biológico de pragas de café Conilon no sudoeste da Amazônia brasileira.

PALAVRAS-CHAVE: Neuropterida, Chrysopoidea, diversidade de espécies, Rubiaceae 


\section{INTRODUCTION}

Brazil is the world's largest producer of coffee in natura, as well as the second largest consumer of the beverage, accounting for $32 \%$ of the world market and with an average annual consumption of $4.89 \mathrm{~kg}$ of roasted coffee per inhabitant (Arantes and Guimarães 2015; Medeiros and Rodrigues 2017). The culture of coffee was introduced to Brazil in the Amazonian state of Pará, but trade in this region only gained economic expression from the middle of the 1970s onwards, through colonization projects that attracted settlers from other Brazilian regions to the Amazon region (Oliveira and Araújo 2015). Coffee in the Amazon is mainly cultivated by small producers, which confers great social importance to this culture. In the state of Acre, in the southwestern Brazilian Amazon, 93\% of coffee plantations have areas of less than 5 ha (Oliveira and Araújo 2015). The most cultivated species in Acre is Coffea canephora Pierre ex Froehner (Rubiaceae), popularly known as Conilon coffee (Bergo et al. 2001). Chemical control is still the most widely used method by coffee farmers to combat crop pest insects, and the use of these products has increased in recent years. From 2000 to 2017 the consumption in tons of active ingredients of pesticides in Brazil has increased by 230\% (Oliveira and Araújo 2015; IBAMA 2019).

Green lacewings (Neuroptera: Chrysopidae) are among the natural enemies of coffee pests that are eliminated collaterally by pesticide use (Silva et al. 2005; Fernandes et al. 2010; Garzón et al. 2015). Chrysopidae is the second largest Neuroptera family, with 1,415 species distributed in all continents, except Antarctica (Oswald and Machado 2018). Green lacewings occupy the first place in number of species among Neuroptera that occur in Brazil, currently with 183 valid species with Brazilian records, of which 114 are endemic (Martins and Machado 2018). Chrysopidae have been prominent in studies aimed at biological pest control, as their larvae are voracious, with great hunting capacity, resistance to various insecticides, high reproductive potential and feed on various soft-bodied prey that are considered pests of different crops, including coffee, such as scales, aphids, whiteflies, eggs and small larvae of Lepidoptera, mites and thrips (Canard and Principi 1984; Albuquerque et al. 1994; Carvalho and Souza 2000; Freitas and Penny 2012).

Due to the importance of Conilon coffee cultivation in Acre, and the high potential of green lacewings for the biological pest control, we carried out a survey of green lacewings in an experimental Conilon coffee plantation in the state, with the aim of determining diversity, abundance and seasonal distribution of Chrysopidae species, to provide information for future biological coffee pest control programs.

\section{MATERIAL AND METHODS}

The study was conducted in two plots planted with Coffea canephora in the Experimental Farm of Embrapa Acre, in the municipality of Rio Branco, Acre state, Brazil $\left(10^{\circ} 01^{\prime} 38.8^{\prime \prime}\right.$ S,6741'09.8”W) (Figure 1). Each plot had an area of 0.25 ha, planted with eight lines of two year old coffee plants distanced $1.5 \mathrm{~m}$ and with $3 \mathrm{~m}$ between lines. The two plots were about $2 \mathrm{~m}$ apart, and formed a joint area of approximately 0.5 ha $\left(88 \times 54 \mathrm{~m}^{2}\right)$. One plot was regularly irrigated twice a day and the other was not irrigated and depended exclusively on rainfall for watering. Both plots were implemented in 2013 and will be referred from here on as the study area. The study area was not submitted to phytosanitary control and is surrounded by Citrus sp. (Rutaceae) and Arachis spp. (Fabaceae) plantations that are not submitted to phytosanitary control either. The nearest native forest area is located at approximately $3 \mathrm{~km}$ from the study area.

Average annual temperature in the region varies from 23.7 to $25.9^{\circ} \mathrm{C}$ with maximum temperatures reaching $33^{\circ} \mathrm{C}$, and average annual precipitation of $1,739 \mathrm{~mm}$. The wettest period occurrs from October to March and the driest from April to September (Duarte 2006). During the study period, the total annual precipitations was about $1,800 \mathrm{~mm}$, average annual temperature was $26^{\circ} \mathrm{C}$ and maximum temperature reached $34^{\circ} \mathrm{C}$ (INMET 2019).

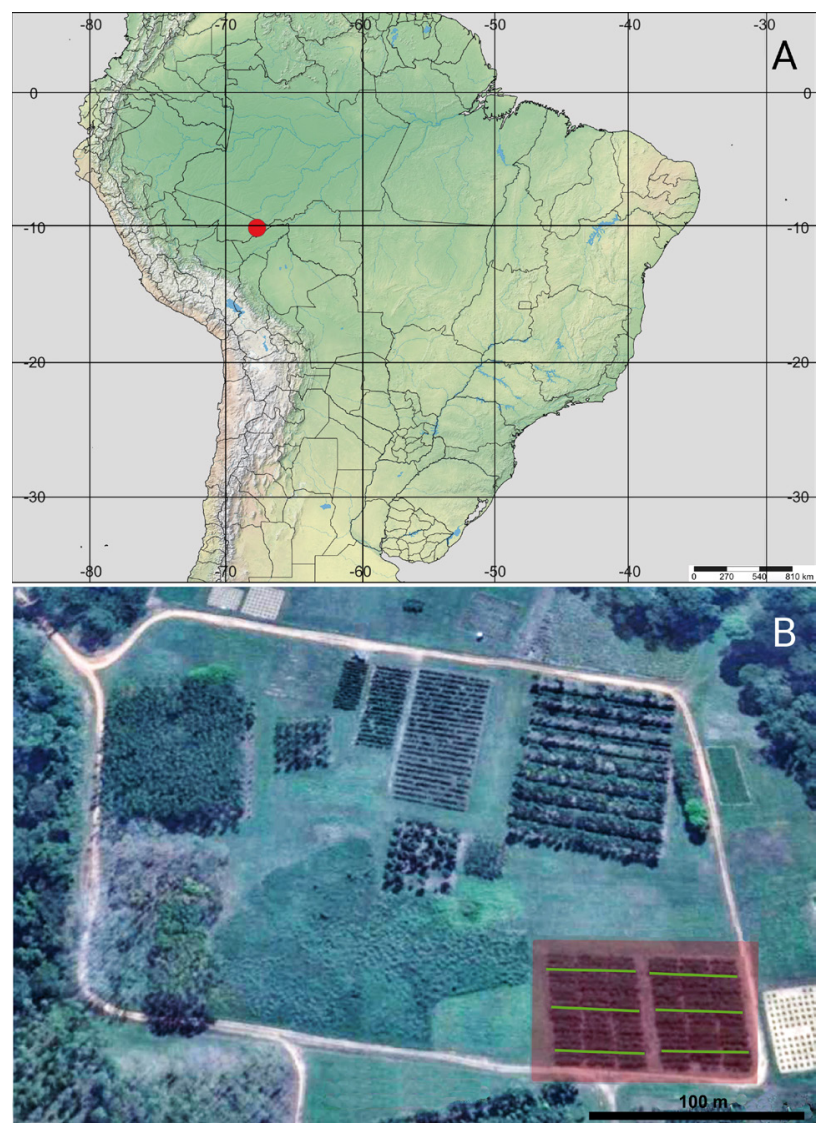

Figure 1. A - Location of the study area in Acre state, southwestern Brazilian Amazon region (map from http://www.simplemappr.net); B - Image of the study area in the exxperimental farm of Embrapa Acre (Rio Branco, Acre, Brazil). The shaded area indicates the two sampling plots of Conilon coffee, and the green lines mark the sampling transects (image from Google Earth Pro). This figure is in color in the electronic version 
The two plots were sampled weekly from September 2015 to September 2016. On each sampling occasion, adult Chrysopidae were collected by a person walking along six transects of approximately $43 \mathrm{~m}$ (Figure 1) hitting an entomological net against both coffee plants and vegetation at the interrows. All Chrysopidae specimens from different transects collected on the same sampling occasion were pooled in one sample. All samplings were performed during $40 \mathrm{~min}$ in the morning (8:00 to 8:40 a.m. local time).

All collected specimens of Chrysopidae were stored in $70 \%$ ethyl alcohol in properly labeled containers and are deposited in the entomological collection "Prof. J.M.F.Camargo" at Universidade de São Paulo, campus Ribeirão Preto. Material identification was carried out by the first author using identification keys in Brooks and Barnard (1990) and Freitas and Penny (2001). When necessary, genitalia were examined using the methodology of Freitas and Penny (2001). The abdominal apex was removed and successively cleared in a solution of $10 \%$ potassium hydroxide $(\mathrm{KOH})$, rinsed with distilled water, stained with Chlorazol Black E., rinsed with distilled water again, and the genitals were stored in tubes with glycerin.

The characterization of the green lacewing assemblage followed the faunal indices in Silveira Neto et al. (1976). To measure diversity and entropy we calculated the Shannon's index, which is based on the proportional abundance of species, considering both richness and equity. Species richness was calculated as the total number of species recorded (S). Species relative frequency (f) was calculated as the ratio of individuals of each species in relation to the total number of individuals collected. Species constancy was measured by the percentage frequency of each species in the overall sample. A species was considered dominant when it had a frequency $>1$ when divided by species richness. The dominance index (D) was calculated, which varies from 0 (all taxa have equal number of individuals in the sample) to 1 (one taxon completely dominates the sample). Simpson's index (1-D) was used to determine the evenness in the species assemblage, a value close to 0 indicates a low uniformity in the sample composition (Magurran 2004). All analyses were made in Excel and the PaSt software (Hammer et al. 2001).

\section{RESULTS}

Overall we collected 1079 specimens of seven species of Chrysopidae (Table 1) on 51 sampling occasions. Ceraeochrysa cubana (Hagen, 1861) was present in $82 \%$ of the samples and was the only constant species in the survey. Ceraeochrysa claveri (Navás, 1911) was present in $26 \%$ of the samples, and was thus considered an accessory species, while the other five species had frequencies below $14 \%$ and were considered accidental occurrences in the study area (Table 1). Ceraeochrysa everes (Banks, 1920), Leucochrysa (Nodita) cruentata (Schneider, 1851) and Chrysoperla externa (Hagen, 1861) were recorded in only one sample. Ceraeochrysa cubana represented $97 \%$ of the captured specimens, and had an accordingly high dominance index (0.9401) and low Simpson index (0.05992).

In general, species occurrence and abundance were irregular along the year (Figure 2). The Shannon index for the overall period was 0.1777 , which indicates low entropy of Chrysopidae in the study area. The highest values for species richness were observed in November and December, when $C$. cubana, C. claveri, C. everes, Ceraeochrysa cincta (Schneider, $1851)$ and $L .(N$.) cruentata occurred in the samples, and in July and August, with the occurrence of C. cubana, C. claveri, C. externa and Leucochrysa (Nodita) marquezi (Navás, 1913) (Figure 2). No specimens were recorded in the beggining of October, and from the end of April to the beginning of May (Figure 2). Ceraeochrysa cubana, which was present in the samples throughout the year, had the largest number of specimens recorded at the end of February, beginning of June and end of July (Figure 2b).

Table 1. Diversity indices of green lacewing species (Chrysopidae, Neuroptera) sampled on Coffea canephora (Conilon coffee) plots in the experimental farm of Embrapa Acre, in Rio Branco (Acre state, Brazil). N = number of specimens.

\begin{tabular}{|c|c|c|c|c|c|}
\hline \multirow{2}{*}{ Species } & \multirow{2}{*}{ N } & \multicolumn{2}{|c|}{ Constancy } & \multirow{2}{*}{$\begin{array}{l}\text { Relative } \\
\text { frequency }\end{array}$} & \multirow{2}{*}{ Dominance } \\
\hline & & Frequency (\%) & Category & & \\
\hline Ceraeochrysa cincta & 2 & 3.9 & Accidental & 0.19 & Non-dominant \\
\hline Ceraeochrysa claveri & 17 & 25.5 & Accessory & 1.58 & Non-dominant \\
\hline Ceraeochrysa cubana & 1046 & 82.4 & Constant & 96.94 & Dominant \\
\hline Ceraeochrysa everes & 1 & 2.0 & Accidental & 0.09 & Non-dominant \\
\hline Chrysoperla externa & 5 & 2.0 & Accidental & 0.46 & Non-dominant \\
\hline Leucochrysa (Nodita) cruentata & 1 & 2.0 & Accidental & 0.09 & Non-dominant \\
\hline Leucochrysa (Nodita) marquezi & 7 & 13.7 & Accidental & 0.65 & Non-dominant \\
\hline Total & 1079 & $100 \%$ & & 100 & \\
\hline
\end{tabular}



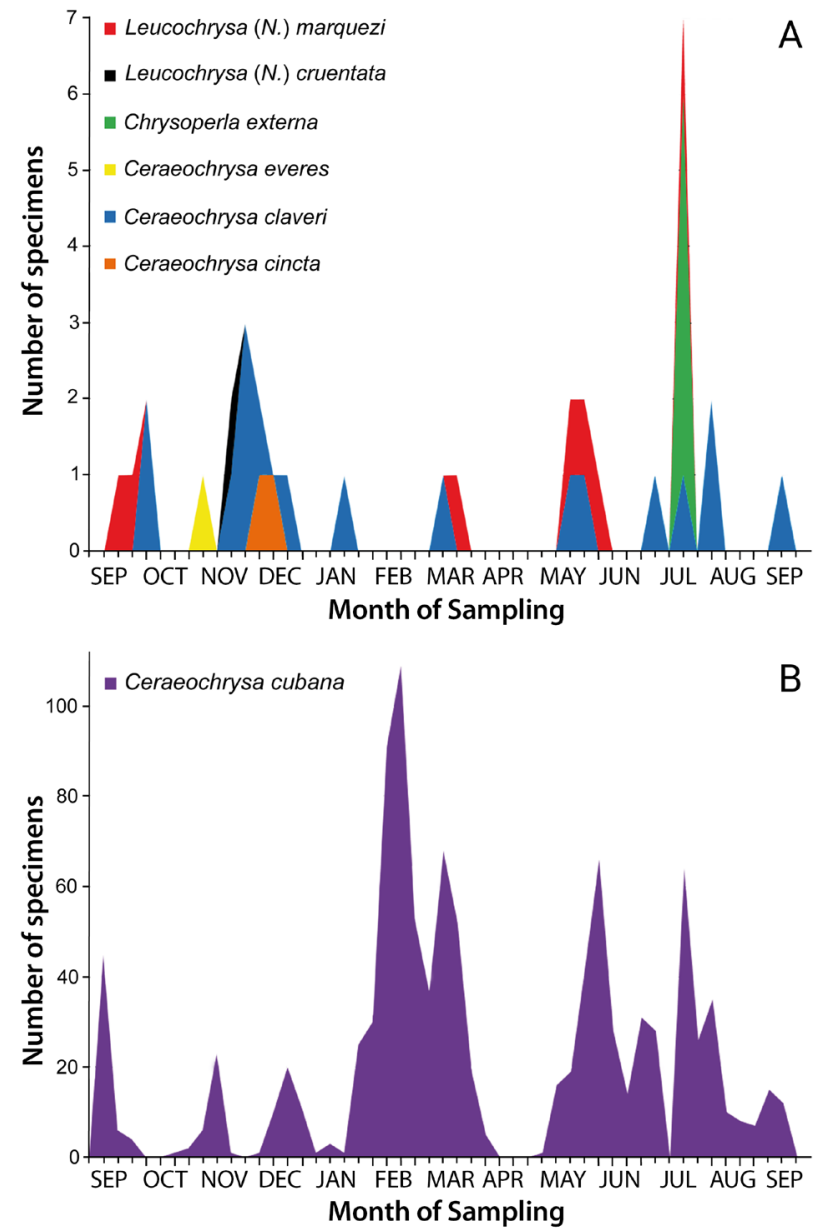

Figure 2. Annual distribution of abundance of green lacewing species (Chrysopidae: Neuroptera) sampled on Coffea canephora (Conilon coffee) plots in the experimental farm of Embrapa Acre, in Rio Branco (Acre state, Brazil). A Accessory and accidental species; B - Dominant species, Ceraeochrysa cubana (Hagen, 1861).This figure is in color in the electronic version

\section{DISCUSSION}

Only three species of two Chrysopidae genera (Chrysoperla externa, Ceraeochrysa nigripes Adams \& Penny, 1987 and C. cubana) had official records for the state of Acre (Martins and Machado 2018), so that in this study we increase the known diversity of Chrysopidae in Acre to three genera and seven species.

A diversity of green lacewings similar to that observed in this study was recorded in Coffea arabica L. plantations in the state of São Paulo, in southeastern Brazil (194 individuals of eight species from three genera) (Montes and Freitas 2010). In C. arabica plantations in the northeastern state of Bahia, 148 individuals of 15 species from four Chrysopidae genera were recorded (Ribeiro et al. 2014). However, these data have to be compared with caution, as species diversity and abundance are dependent on sampling effort. Montes and Freitas (2010) and Ribeiro et al. (2014) also used weekly entomological- net samplings, but over shorter periods of nine and eight months, respectively. They also used McPhail traps, which allow the sampling of species that occur in the afternoon and evening periods, and which were not sampled in our study. It is notable that the abundance of individuals (represented predominantly by $C$. cubana) was considerably higher in our survey than in the two latter studies. Ceraeochrysa cubana, C. cincta, C. everes, Chrysoperla externa and $L$. (N.) cruentata occurred in coffee plantations in Acre, Bahia and São Paulo, while $C$. claveri occurred in Acre and São Paulo, and $L$. $(N$.) marquezi occurred only in Acre (Montes and Freitas 2010; Ribeiro et al. 2014, this study).

The diversity of green lacewing species and the low abundance of most species in our study site may be owed to the sampling method and period, as it left out species with crepuscular and nocturnal habits (Oswald and Machado 2018). Environmental temperature may also have played a role, as mean annual maximum temperature in the region is about $5{ }^{\circ} \mathrm{C}$ above the optimum temperature for Chrysopidae development (Albuquerque et al. 1994; Figueira et al. 2000; Pessoa et al. 2004; Pappas et al. 2008). Our coffee plots were in full sun, which may also have contributed to lower lacewing occurrence, as the presence of surrounding trees provides shade and landscape heterogeneity, acting as refuges for invertebrate fauna and increasing the biodiversity of the habitat (Ricci et al. 2006; Santos and Pérez-Maluf 2012). The absence of native forest surrounding our study area is also likely to reduce the diversity of native insect fauna, since the presence of this vegetation, as in agroforest systems, allows the dispersion of pest natural enemy species (Ribeiro et al. 2014), and acting as a reservatory of insect diversity. More diverse habitats tend to have larger populations of pest natural enemy species (Altieri 2004).

This is the first record of C. cubana as a dominant species in a crop system. The species had already been recorded in a number of different cultures, such as peach [Prunus persica (Linnaeus)], coffee (C. arabica), acerola (Acerola emarginata D. C.), manioc (Manihot sp.), eucalyptus (Eucaliptus sp.), pinus (Pinus sp.), mango (Mangifera indica L.), sweet potato (Ipomoea batatas (L.) Lam), pumpkin (Curcubita sp.), citros (Citrus spp.), melon (Cucumis melo L.), almond (Prunus dulcis (Mill.) D. A. Webb) and avocado (Persea americana Mill.) (Bezerra et al. 2010, Monte and Freitas 2010, Ribeiro et al. 2014; Caleb C. Martins, pers. comm.), but in all cases $C$. externa or C. cincta was the dominant species (Bezerra et al. 2010, Monte and Freitas 2010, Ribeiro et al. 2014). In this sense, the low number of $C$. externa in our study was surprising, as it usually occurs with high frequency when it is present in crops as diverse as coffee, peach, acerola, eucalyptus, mango and pumpkin (Montes and Freitas 2010; Ribeiro et al. 2014). Populations of C. externa increase during cool and dry periods (Souza and Carvalho 2002), which may explain the low frequency of this species in the humid tropical conditions of our study. 
Ceraeochrysa cubana population had two frequency peaks, at the end of February, when the rainy season is ending, and coinciding with the period of coffee fruit maturation (Amaral et al. 2018), and in June-July, during the dry season, coinciding with the end of the physiological rest period and the beginning of the flowering of Conilon coffee (Amaral et al. 2018). So the peaks of C. cubana abundance coincided with periods of high availability of food sources for Chrysopidae adults (Canard 2001), which likely made the coffee plantation attractive to them. From the end of April to beginning of May, when no green lacewing was collected, Conilon coffee tree branches are in resting and senescence (Amaral et al. 2018).

Ceraeochrysa cubana is widespread in the Neotropics, has resistance to various insecticides (Cordeiro et al. 2010; Ono et al. 2017) and preys on several agricultural pests, such as Spodoptera frugiperda (Smith, 1797) (Lepidoptera: Noctuidae) (Nunes et al. 2017), Aleurocanthus woglumi Ashby, 1915 (Hemiptera: Aleyrodidae) (Oliveira et al. 2016) and Aphis gossypii Glover, 1877 (Hemiptera: Aphididae) (Alcantra et al. 2008). Our results suggest that $C$. cubana is well adapted to the climatic and environmental conditions in Acre, and may be a suitable candidate for use in biological control programs for coffee pests in Acre, such as Praelongorthezia praelonga (Douglas, 1891) (Hemiptera: Ortheziidae), Leucoptera coffeella (GuérinMèneville \& Perrottet, 1842) (Lepidoptera: Lyonetiidae) and Brevipalpus phoenicis (Geijskes, 1939) (Acari: Tenuipalpidae), which are known to be predated by other Chrysopidae species (Chrysopa sp. and C. externa) (Silva et al. 2006; Costa et al. 2009; Fornazier et al. 2017). Further long-term studies on a wider geographical scale should confirm the constance and dominance of C. cubana in coffee plantations in Acre.

\section{CONCLUSIONS}

A year-long survey on an experimental Conilon coffee plantation in Acre (southwestern Brazilian Amazon) detected seven green lacewing species, resulting in low Shannon diversity and evenness indices for Chrysopidae in the study area. Ceraeochrysa cubana was the dominant species, occurring in $82 \%$ of the weekly samples, and accounting for $97 \%$ of all specimens collected. These results suggest that C. cubana is well adapted to local climatic conditions. As this species is known to prey on several agricultural pests and shows resistance to various insecticides, it may be a suitable candidate for biological control programs of Conilon coffee pests in this region.

\section{ACKNOWLEDGMENTS}

We are grateful to Embrapa Acre (Empresa Brasileira de Pesquisa Agropecuária) for making the areas of coffee Conilon available for this study, to Biol. Elisandro Nascimento da Silva for his help in field samplings, and to Dr. Claudia Keller and two anonymous reviewers for their suggestions on previous versions of the manuscript. The first author is grateful to Coordenação de Aperfeiçoamento de Pessoal de Nível Superior - CAPES/Brasil for a doctoral scholarship (Code 001) .

\section{REFERENCES}

Albuquerque, G.S.; Tauber, C.A.; Tauber, M.J. 1994. Chrysoperla externa (Neuroptera: Chrysopidae): life history and potencial for biological control in Central and South America. Biological Control, 4: 7-13.

Alcantra, E.; Carvalho, C.F.; dos Santos, T.M.; Souza, B.; SantaCecilia, L.V.C. 2008. Biological aspects and predatory capacity of Ceraeochrysa cubana (Hagen, 1861) (Neuroptera: Chrysopidae) fed on Aphis gossypii Glover, 1877 (Hemiptera: Aphididae) under different temperatures. Ciência e Agrotecnologia, 32: 1047-1054.

Altieri, M.A. 2004. Agroecologia: a dinâmica produtiva da agricultura sustentável. 4th ed. Editora UFRGS, Porto Alegre, 110p.

Amaral, E.F.; Martorano, L.G.; Bergo, C.L.; Moraes, J.R.S.C.; Lunz, A.M.P.; Souza, L.P.; Araújo, E.A.; Bardales, N.G.; Lima, M.N. 2018. Condições agroclimáticas para subsidiar cultivos de café canéfora no Acre. In: Bergo, C.L.; Bardales, N.G. (Eds.). Zoneamento Edafoclimático para o Cultivo do Café Canéfora (Coffea canephora) no Acre. Empresa Brasileira de Pesquisa Agropecuária, Brasília, p.49-90.

Arantes, A.; Guimarães, L.G. 2015. Guia para Produção de Café Sustentável na Amazônia: Experiência de Apuí (AM). Instituto de Manejo e Certificação Florestal e Agrícola/ Instituto de Conservação e Desenvolvimento Sustentável do Amazonas, Piracicaba, 33p.

Bergo, C.L.; Amaral, E.F.; Araújo, E.A.; Bardales, N.G.; Pereira, R.C.A. 2001. Aptidão Natural para o Cultivo do Café (Coffea canephora) no Estado do Acre. Comunicado Técnico Embrapa, 126: 1-4.

Bezerra, C.E.S.; Tavares, P.K.A.; Macedo, L.P.M.; De Freitas, S.; Araújo, E.L. 2010. Green Lacewings (Neuroptera: Chrysopidae) Associated with Melon Crop in Mossoró, Rio Grande do Norte state, Brazil. Neotropical Entomology, 39: 454-455.

Brooks, S.J.; Barnard, P.C. 1990. The green lacewings of the world: a generic review (Neuroptera: Chrysopidae). The Bulletin of the British Museum 59: 117-286.

Canard, M. 2001. Natural food and feeding habits of lacewings. In: Mcewen, P.; New, T.R.; Whittington, A.E. (Eds.). Lacewings in the crop environment. Cambridge University Press, Cambridge, p.116-129.

Canard, M.; Principi, M.M. 1984. Development of Chrysopidae. In Canard, M.; Séméria, Y.; New, T.R. (Eds.). Biology of Chrysopidae. MTP Press, Lancaster, p.57-75.

Carvalho, C.F.; Souza, B. 2000. Métodos de criação e produção de crisopídeos. In: Bueno, V.H.P. (Ed.). Controle biológico de pragas: produção massal e controle de qualidade. Editora Universidade Federal de Lavras, Lavras, p.91-109.

Cordeiro, E.M.G.; Corrêa, A.S.; Venzon, M.; Guedes, R.N.C. 2010. Insecticide survival and behavioral avoidance in the lacewings Chrysoperla externa and Ceraeochrysa cubana. Chemosphere, 81: 1352-1357.

Costa, J.N.M.; Teixeira, C.A.D.; Sallet, L.A.P.; Gama, F.C. 2009. Cochonilhas ocorrentes em cafezais de Rondônia. Comunicado Técnico Embrapa, 110: 1-6.

De Freitas, S.; Penny, N.D. 2001. The green lacewings (Neuroptera: Chrysopidae) of Brazilian agro-ecosystems. Proceedings of the California Academy of Sciences, 52: 245-395.

De Freitas, S.; Penny, N.D. 2012. Neuroptera. In: Rafael, J.A.; Melo, G.A.R.; Carvalho, C.J.B.; Casari, S.A.; Constantino, R. (Eds.). 
Insetos do Brasil: diversidade e taxonomia. Holos Editora, Ribeiráo Preto, p. 537-546.

Duarte, A.F. 2006. Aspectos da climatologia do Acre, Brasil, com base no intervalo 1971-2000. Revista Brasileira de Meteorologia, 21:308-317.

Fernandes, F.L; Bacci, L.; Fernandes, M.S. 2010. Impact and selectivity of insecticides to predators and parasitoids. Entomo Brasilisis, 3: 1-10.

Figueira, L.K.; Carvalho, C.F.; Souza, B. 2000. Biologia e exigências térmicas de Chrysoperla externa (Hagen, 1861) (Neuroptera: Chrysopidae) alimentada com ovos de Alabama argillacea (Hübner, 1818) (Lepidoptera: Noctuidae). Ciência e Agrotecnologia, 24: 319-326.

Fornazier, M.J.; Martins, D.S.; Fanton, C.J.; Benassi, V.L.R.M. 2017. Manejo de Pragas do Café Conilon. In: Ferrão, R.G.; Fonseca, A.F.A.; da Bragança, S.M.; Ferrão, M.A.G.; De Muner, L.H. (Eds.) Café Conilon. Instituto Capixaba de Pesquisa, Assistência Técnica e Extensão Rural, Vitória, Espírito Santo, p.407-449.

Garzón, A.; Amor, P.M.F; Budia, E.V. 2015. Toxicity and sublethal effects of six insecticides to last instar larvae and adults of the biocontrol agents Chrysoperla carnea (Stephens) (Neuroptera: Chrysopidae) and Adalia bipunctata (L.) (Coleoptera: Coccinellidae). Chemosphere, 132: 87-93.

Hammer, Ø.; Harper, D.A.T.; Ryan, P.D. 2001. PAST: Paleontological Statistics Software Package for Education and Data Analysis. Palaeontologia Electronica, 4: 1-9.

IBAMA. 2019. Instituto Brasileiro do Meio Ambiente e dos recursos Naturais Renováveis. Relatórios de comercialização de agrotóxicos. (www.ibama.gov.br/agrotoxicos/relatorios-de-comercializacao-deagrotoxicos). Accessed on 06 Jun 2019.

INMET. 2019. Instituto Nacional de Meteorologia. Clima. (www. inmet.gov.br/portal/index.php?r=clima). Accessed on 04 Jun 2019.

Magurran, A.E. 2004. Measuring biological Diversity. Blackwell Publishing, Oxford, 256p.

Martins, C.C.; Machado, R.J.P. 2018. Chrysopidae. In: Boeger, W.A.; Zager, H.; Rafael, J.A.; Valim, M.P. (Eds.). Catálogo Taxonômico da Fauna do Brasil. Programa das Naçóes Unidas para o Desenvolvimento/ Universidade Federal do Rio de Janeiro/ Instituto Alberto Luiz Coimbra de Pós-Graduação e Pesquisa de Engenharia, Rio de Janeiro, 644p.

Medeiros, R.V.V.; Rodrigues, P.M.A. 2017. A economia cafeeira no Brasil e a importância das inovaçóes para essa cadeia. A Economia em Revista 25: 1-12.

Montes, S.M.N.M.; De Freitas, S. 2010. Ocorrência de inimigos naturais (bicho lixeiro) em agroecossistemas, na alta Sorocabana, estado de São Paulo. Pesquisa \& Tecnologia, 7:1.

Nunes, G.S.; Nascimento, I.N.; Souza, G.M.M.; Oliveira, R.; Oliveira, F.Q.; Batista, J.L. 2017. Biological aspects and predation behavior of Ceraeochrysa cubana against Spodoptera frugiperda. Revista Brasileira de Ciências Agrárias, 12: 20-25.

Oliveira, R.; Barbosa, V.D.; Vieira, D.L.; Oliveira, F.Q.; Batista, J.D.; de Brito, C.H. 2016. Development and reproduction of Ceraeochrysa cubana (Neuroptera: Chrysopidae) fed with Aleurocanthus woglumi (Hemiptera: Aleyrodidae). Semina: Ciências Agrárias, 37: 17-23.
Oliveira, S.J.M.; Araújo, L.V. 2015. Aspectos econômicos da cafeicultura. In: Marcolan, A.L.; Espindula, M.C. (Eds.). Café na Amazônia. Empresa Brasileira de Pesquisa Agropecuária, Brasília, p.27-40.

Ono, E.K.; Zanardi, O.Z.; Santos, K.F.A.; Yamamoto, P.T. 2017. Susceptibility of Ceraeochrysa cubana larvae and adults to six insect growth-regulator insecticides. Chemosphere, 168: 49-57.

Oswald, J.D.; Machado, R.J.P. 2018. Biodiversity of the Neuropterida (Insecta: Neuroptera: Megaloptera, and Raphidioptera). In: Foottit, R.G.; Adler, P.H. (Eds.). Insect Biodiversity: Science and Society. 1st ed. John Wiley \& Sons, New York, p.627-671.

Pappas, M.L.; Broufas, G.D.; Koveos, D.S. 2008. Effect of temperature on survival, development and reproduction of the predatory lacewing Dichochrysa prasina (Neuroptera: Chrysopidae) reared on Ephestia Kuehniella eggs (Lepidoptera: Pyralidae). Biological Control, 45: 396-403.

Pessoa, L.G.A.; Leite, M.V.; De Freitas, S.; Garbin, G.C. 2004. Efeito da variação da temperatura sobre o desenvolvimento embrionário e pós-embrionário de Ceraeochrysa paraguaria (Navás) (Neuroptera: Chrysopidae). Arquivos do Instituto Biológico, 71: 473-476.

Ribeiro, A.E.L.; Castellani, M.A.; Pérez-Maluf, R.; Moreira, A.A.; Leite, S.A.; Costa, D.R. 2014. Ocurrence of green lacewings (Neuroptera: Chrysopidae) in two coffee cropping systems. African Journal of Agricultural Research, 9: 1597-1603.

Ricci, M. dos S.F.; Costa, J.R.; Pinto, A.N.; Santos, V.L.S. 2006. Cultivo orgânico de cultivares de café a pleno sol e sombreado. Pesquisa Agropecuária Brasileira 41: 569-575.

Santos, P.S.; Pérez-Maluf, R. 2012. Diversidade de himenópteros parasitoides em áreas de mata de cipó e cafezais em Vitória da Conquista-Bahia. Magistra, 24: 84-90.

Silva, R.A.; Carvalho, G.A.; Carvalho, C.F.; Reis, P.R.; Pereira, A.M.A.R.; Cosme, L.V. 2005. Toxicidade de produtos fitossanitários utilizados na cultura do cafeeiro a larvas de Chrysoperla externa (Hagen) (Neuroptera: Chrysopidae) e efeitos sobre as fases subsequentes do desenvolvimentos do predador. Neotropical Entomology, 34: 951-959.

Silva, R.A.; Reis, P.R.; Carvalho, C.F.; Souza, B. 2006. Predatory capacity of Chrysoperla externa (Hagen, 1861) (Neuroptera: Chrysopidae) on Brevipalpus phoenicis (Geijskes, 1939) (Acari: Tenuipalpidae. Coffee Science, Lavras, 1: 50-54.

Silveira Neto, S; Nakano, O.; Vila Nova, N.A. 1976. Manual de Ecologia dos Insetos. Agronômica Ceres, Piracicaba, 419p.

Souza, B.; Carvalho, C. F. 2002. Population dynamics and seasonal occurrence of adults of Chrysoperla externa (Hagen, 1861) (Neuroptera: Chrysopidae) in a citrus orchard in southern Brazil. Acta Zoologica Academiae Scientiarum Hungaricae, 48 (Suppl. 2): 301-310.

RECEIVED: 04/02/2019

ACCEPTED: $27 / 05 / 2019$

ASSOCIATE EDITOR: Fabrício B. Baccaro 